\title{
Porcine Uterine and Placental Extracellular Matrix Molecules Throughout Pregnancy
}

\author{
Moléculas de la Matríz Extracelular Placentaria y Uterina Durante la Preñez Porcina
}

****E. G. Sanchis; *A. L. Cristofolini; *A. Taglialegna \& *C. I. Merkis

SANCHIS, E. G.; CRISTOFOLINI, A. L.; TAGLIALEGNA, A. \& MERKIS, C. I. Porcine uterine and placental extracellular matrix molecules throughout pregnancy. Int. J. Morphol., 29(4):1438-1443, 2011.

SUMMARY: The molecules that constitute the extracellular matrix are important in several functions related to tissue support and cell-cell, cell-extracellular matrix interaction. Among the macromolecules that constitute the mentioned matrix we find osteopontin, fibrinogen and collagen. The present study was undertaken to analyze the rol of osteopontin, fibrinogen and collagen in uterine-placental interface during normal porcine gestation. Uterine and placental tissues from crossbred gilts of $30(n=5), 60(n=5), 70(n=5)$ and $114($ at term, $n=5$ ) days of gestation were used. Macroscopic analysis of the embryos/fetuses allowed us to determine their gestational age by means of the crown-rump lenght. Haematoxylin-Eosin and Masson's Trichrome dyes along with light microscopy were used to structure analysis of every selected period of gestation. A spacial and temporal study of osteopontin and fibrinogen was performed through immunohistochemical technique. Determination of collagen fibers was carried out through Picrosirius red technique and polarizing microscopy. Results were expressed as semi-quantitative. Higher expression of osteopontin was observed at early periods of gestation, mainly in uterine and placental villi, endometrial gland epithelium and histotroph. Fibrinogen expressed abundantly in fetal mesenchyme in every period analyzed and in fetal and maternal vessels at Day 70. Negative expression of collagen fibers was observed in villi, however increasing expression of thick fibers throughout pregnancy was detected in uterine stroma and myometrium. These results confirm the importance of osteopontin, fibrinogen and collagen in the support of uterine and placental structures and in the suitable maintenance of pregnancy.

KEY WORDS: Pig; Placenta; Osteopontin; Fibrinogen; Collagen.

\section{INTRODUCTION}

Porcine placenta is diffuse, folded, adeciduate, non invasive and epitheliochorial, accomplished with interdigitations of the trophoectoderm microvilli and surface uterine epithelium (Wooding \& Burton, 2008). These villi experiment a marked development until Day 55 of gestation, while their epithelial area increases mainly at term, guaranteeing maternal-conceptus interchange (Merkis et al., 2005). It is widely accepted that in animals with this placentation pattern, communication between maternal and fetal tissues highly depends on precise cell-cell and cellextracellular matrix interactions (Rashev et al., 2005). Furthermore, it has been established that extracellular matrix $(\mathrm{ECM})$ plays a key role in stromal architecture and resident mesenchymal cells contribute significantly to its production (Sati et al., 2008).
The osteopontin (OPN) is a well studied glycoprotein, which binds to several receptors through an Ar-Gly-Asp (RGD) aminoacid sequence (Garlow et al., 2002). It is a constituent of the placental ECM and it has also been found in porcine histotroph and maternal-fetal interface (Johnson et al., 2003; Joyce et al., 2005; Sanchis et al., 2009) with variations according to species and placentation pattern (Garlow et al.). Previous reports have demonstrated its participation in several physiologic and molecular processes, for example, stimulation of cell-cell adhesion, increase of the cell-extracellular matrix communication and signal transduction (Johnson et al.). Its presence in the placenta of animals with different types of placentation has, for several years, encouraged researchers to elucidate its rol in critical periods along pregnancy (Garlow et al.; Joyce et al.; Sanchis et al., 2009; Sanchis et al., 2010).

\footnotetext{
*Electron Microscopy Area, Department of Animal Pathology, Faculty of Agronomy and Veterinary, National University of Río Cuarto, Córdoba, Argentina.

*** Consejo Nacional de Investigaciones Científicas y Técnicas, CONICET, Argentina.

This study was partly supported by grant A539 of SECyT UNRC and by CONICET/MinCyTCba.
} 
Other ECM component, the fibrinogen $(\mathrm{Fg})$, is a glycoprotein present in blood plasma, precursor of fibrin. It binds to different growth factors, potencially stimulating the proliferation of endothelial cells. During pregnancy there is an augmentation of blood flow to the uterus to satisfy the increasing metabolic demands of conceptuses, which is essential in the transplacental interchange throughout gestation (Reynolds et al., 2006). A number of researchers have established that there is an intimate relation between the increase of blood flow of the placenta and the formation and growth of the placental vascular system, known as angiogenesis (Merkis et al., 2006; Reynolds et al.), in which Fg is involved (Cristofolini et al., 2008). It has been indicated that in absence of fibrinogen there is a separation of the feto-placental unit from the uterine wall causing the complete loss of placental integrity and a fatal hemorrhage (Iwaki et al., 2002). As a result of the above stated, it can be inferred that fibrinogen is critical in the maintenance of pregnancy (Iwaki \& Castellino, 2005).

Among the macromolecules that constitute the placental ECM, we also find the collagen system with different localizations in the embryo-maternal tissues. It is the main protein of the extracellular matrix, produced mainly by fibroblasts (Esteban et al., 2005) and composes approximately $20 \%$ of placental tissues. Every molecule generally has one or more binding sites that bind to other components of matrix or other cells, allowing the formation of a vast net of communication. These fibers play a vital rol in maintaining structural integrity and in determining tissue function (Rich \& Whittaker, 2005) and their involvement in placenta composition has already been emphasized in humans (Sati et al.).

Since placental development, required for a succesful gestation in any mammal species, is intimately related to the proliferation of placental cells and the production of extracellular matrix (Arai \& Nishiyama, 2007), an in-depth analysis of some of these molecules results necessary. Preliminary studies on ECM molecules in pig placenta have been carried out by our team (Cristofolini et al.; Merkis et al., 2009; Sanchis et al., 2009). However, the existing relation among them is not yet clear and some new approaches to the topic are needed. The purpose of this paper is to examine the temporal and spacial distribution of porcine uterine and placental osteopontin, fibrinogen and collagen throughout pregnancy. This knowledge may illuminate the functions of these molecules in maternal-fetal interaction.

\section{MATERIAL AND METHOD}

Animals and tissue collection. Animal reproductive tracts used in this study came from different slaughterhouses located in Río Cuarto, Argentina $\left(33.11^{\circ} \mathrm{S} ; 64.3^{\circ} \mathrm{O}\right)$. According to the antemortem and postmortem examinations, the animals were considered free of disease. Reproductive tracts from twenty crossbred gilts were removed and processed in the lab. The tracts were washed with Hank's saline solution ( $\mathrm{SSH}$ ) (Gibco, Grand Island, NY USA) containing $10,000 \mathrm{U} / \mathrm{ml}$ of sodic penicillin $\mathrm{G}, 10 \mathrm{mg} / \mathrm{ml}$ of streptomycine sulphate and $2.5 \mathrm{mg} / \mathrm{ml}$ of fungizone (Gibco, Grand Island, NY USA) and maintained at $4^{\circ} \mathrm{C}$ until processing. The uterine horns were opened carefully and longitudinally with an incision on the anti-mesometrial edge and the embryos/fetuses were taken out for examination. The gestational age of the placentas was determined according to the crown-rump length (CRL) of the embryos and/or fetuses obtained from each gestating bristle (Marrable, 1971). Slaughtered animals (five per group) corresponded to $30,60,70$ and 114 days of pregnancy (the day of coitus was designated as Day 0 of gestation). Samples of mesometrial, endometrial, and fetal placental tissues were obtained. Portions of approximately $6 \mathrm{~mm}$ each were taken from five placentae of every gestational period, fixed in 4 per cent $(\mathrm{v} / \mathrm{v})$ buffered-saline formaldehyde, $\mathrm{pH}$ 7.2-7.4 at $4^{\circ} \mathrm{C}$ and embedded in paraffin. Histologic sections $( \pm 4 \mu \mathrm{m})$ were cut with a microtome (Microm, Germany).

Immunohistochemical analysis. For detection and analysis of osteopontin and fibrinogen, immunohistochemical technique was performed using commercial antibodies ( Ramos-Vara, 2005). Simultaneously, immunohistochemical negative controls were carried out using an irrelevant IgG. Briefly, sections were blocked with $3 \%(\mathrm{v} / \mathrm{v})$ hydrogen peroxide for $5 \mathrm{~min}$ and incubated $1 \mathrm{~h}$ with primary antibodies: mouse monoclonal anti-OPN (code sc-21742, working dilution 1/200, Santa Cruz Biotechnology, Inc.; Santa Cruz, CA, U.S.A.) or rabbit polyclonal antiserum to swine fibrinogen (code RASw/Fbg, working dilution 1/800; Nordic Immunology; Tilburg, The Netherlands) for $1 \mathrm{~h}$. Amplification of the primary antibody reaction was achieved using anti-rabbit, anti-mouse and anti-goat biotinylated secundary antibodies pool for $20 \mathrm{~min}$, followed by a complex of streptavidin conjugated to horseradish peroxidase (LSAB+ System-HRP, code K0690, Dako Cytomation; Glostrup, Denmark) for $20 \mathrm{~min}$. Finally, the binding was visualized by the addition of 3,3'-diaminobenzidine (DAB) chromogen solution (Liquid DAB+ Substrate Chromogen System, code K3468, Dako Cytomation; Glostrup, Denmark) for $15 \mathrm{~min}$. Between each step the sections were washed with PBS for $10 \mathrm{~min}$. The entire technique was performed at room temperature. The sections were counterstained with Mayer's haematoxylin for $50 \mathrm{sec}$, washed with $0.08 \%$ ammonium hidroxide for $30 \mathrm{sec}$ and dehydrated with increasing graduation of alcohols. The slides were cover-slipped in Entellan (Merk, Germany) embedding agent. The staining 
intensity was evaluated by a semi-quantitative scoring system as follows: $(-)$ : negative, $(+)$ : weak, $(++)$ : moderate and $(+++)$ : strong immunostaining.

Picrosirius red analysis.In order to evaluate the spatial distribution of collagen fibers in uterine and placental tissues along gestation, Picrosirius red stain and polarizing microscopy were carried out. Collagen fibers appeared green, yellow, orange or red, in sequence of increasing thickness, independently of collagen type. Briefly, slides were stained with Weigert haematoxylin to highlight nuclei and then washed with running water for $10 \mathrm{~min}$. Then the slides were incubated with Picrosirius red solution for $1 \mathrm{~h}$ and washed twice with acid water. They were then dried and dehydrated with $100 \%$ ethanol and xilol, mounted with Entellan (Merk, Germany) and overlaid with a coverglass. Results were expressed assemi-quantitative assessment of colour intensities. Presence of each type of collagen fiber: (-): negative, (+): weak, $(++)$ : abundant, and $(+++)$ : high expression.

Photomicrography. Photomicrographs of representative fields of immunohistochemistry were evaluated with an Axiophot microscope (Carl Zeiss, Thornwood, NY) fitted with an Axiocam high resolution digital camera. Digital images were captured with an Axiovision 4.6.3 software. Photomicrographs of representative fields of Picrosirius red were evaluated with a Nikon Eclipse E-600 POL polarized light microscope (Nikon Inc., Melville, NY) and images taken with a Powershot G6, 7.1 megapixels digital camera (Canon Inc., Japan).

Data analysis. A low number of samples were used due to the difficulty of obtaining animals of different periods of gestation. As a result, the statistical analysis was limited to descriptive statistics (Kuehl, 2001), the variable intensity of immunostaining or color for each pregnancy stage in different tissue structures could be observed.

\section{RESULTS}

Immunohistochemistry. Osteopontin immunoreactivity. At Day \pm 30 strong immunostaining of OPN was found in the uterine luminal and trophoectoderm epithelia, while moderate OPN was detected in stroma and in the glandular epithelium (Fig. 1a). At Days 60 and 70 immunostaining revealed the presence of OPN only in stroma and fetal mesenchyme (Fig. 1b). In term placentas only weak immunoreactivity was observed in mesenchyme (Fig. 1c). It is important to highlight that OPN was detected in the histotroph of every period studied. In blood vessels, only the adventitia was found reactive to the protein of every period analysed with exception of Day 70. No unspecified OPN binding was detected in negative control slide.

Fibrinogen immunoreactivity. No $\mathrm{Fb}$ was detected in luminal uterine and conceptus trophoectoderm epithelia in any period studied (Fig. 2a-c). However, the opposite was found in connective tissue (Fig. 2a-c). Uterine stroma and conceptus trophoblast expressed moderate immunoreactivity to the protein in every period evaluated, with exception of Day 60 in which uterine stroma expressed weak. No reaction was observed in endometrial gland epithelium in any period analysed. However it is important to highlight that maternal and fetal blood vessels expressed Fb only at Day 70 (Fig. 2b). No unspecified Fg binding was detected in negative control slide.

Picrosirius red staining. Collagen staining. As expected, at polarized light microscopy no expression of collagen fibers was found in uterine and placental villi of any period studied. However, high expression of collagen fibers of different thickness was detected in connective tissue of every period analyzed (Fig. 3a-d). Abundant fibers of different thickness were found along gestation. As predicted, thickness of detected fibers augmented throughout pregnancy. Similar findings appeared in maternal myometrium.

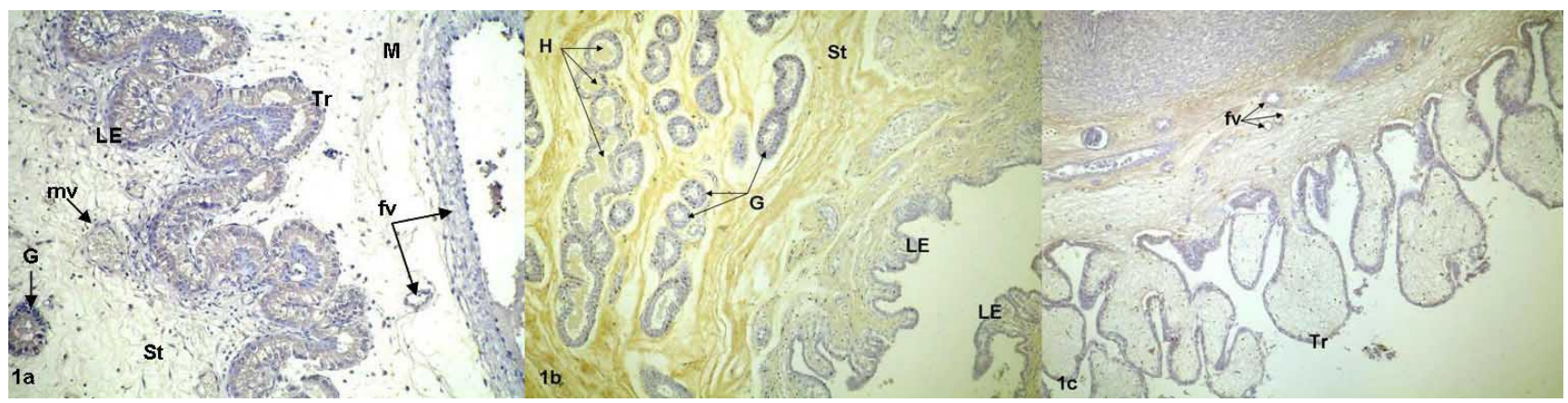

Fig. 1. Osteopontin immunostaining at Day 30 (a, 200x); 60 (b, 100x), and 114 (c, 200x) of pregnancy. Tr: trophoectoderm, LE: luminal epithelium, St: stroma, M: fetal mesenchyme, mv: maternal vessels, fv: fetal vessels, G: glandular epithelium, H: histotroph. 


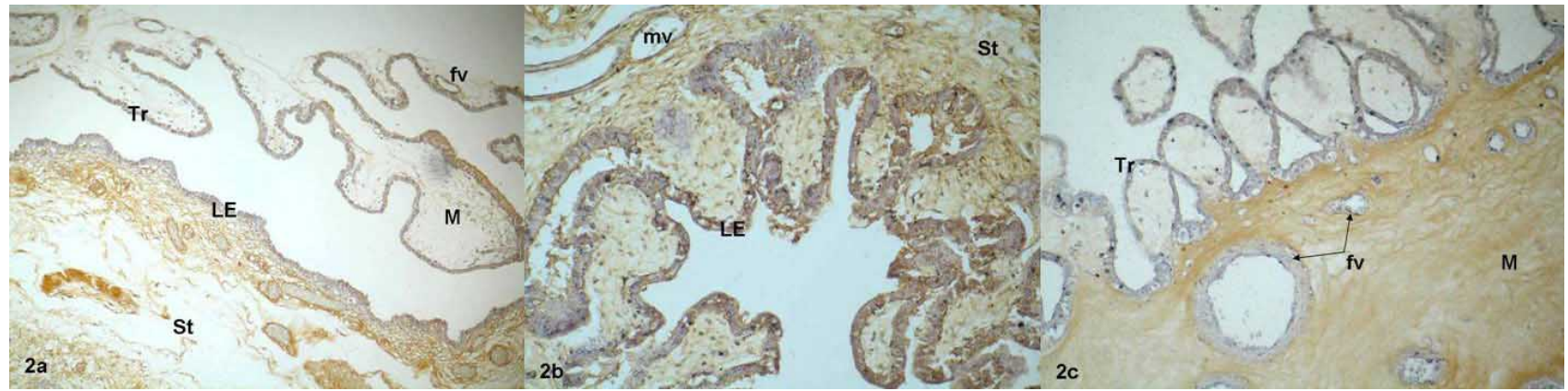

Fig. 2. Fibrinogen immunostaining at Day 30 (a, 100x), 70 (b, 200x), and 114 (c, 100x) of pregnancy.

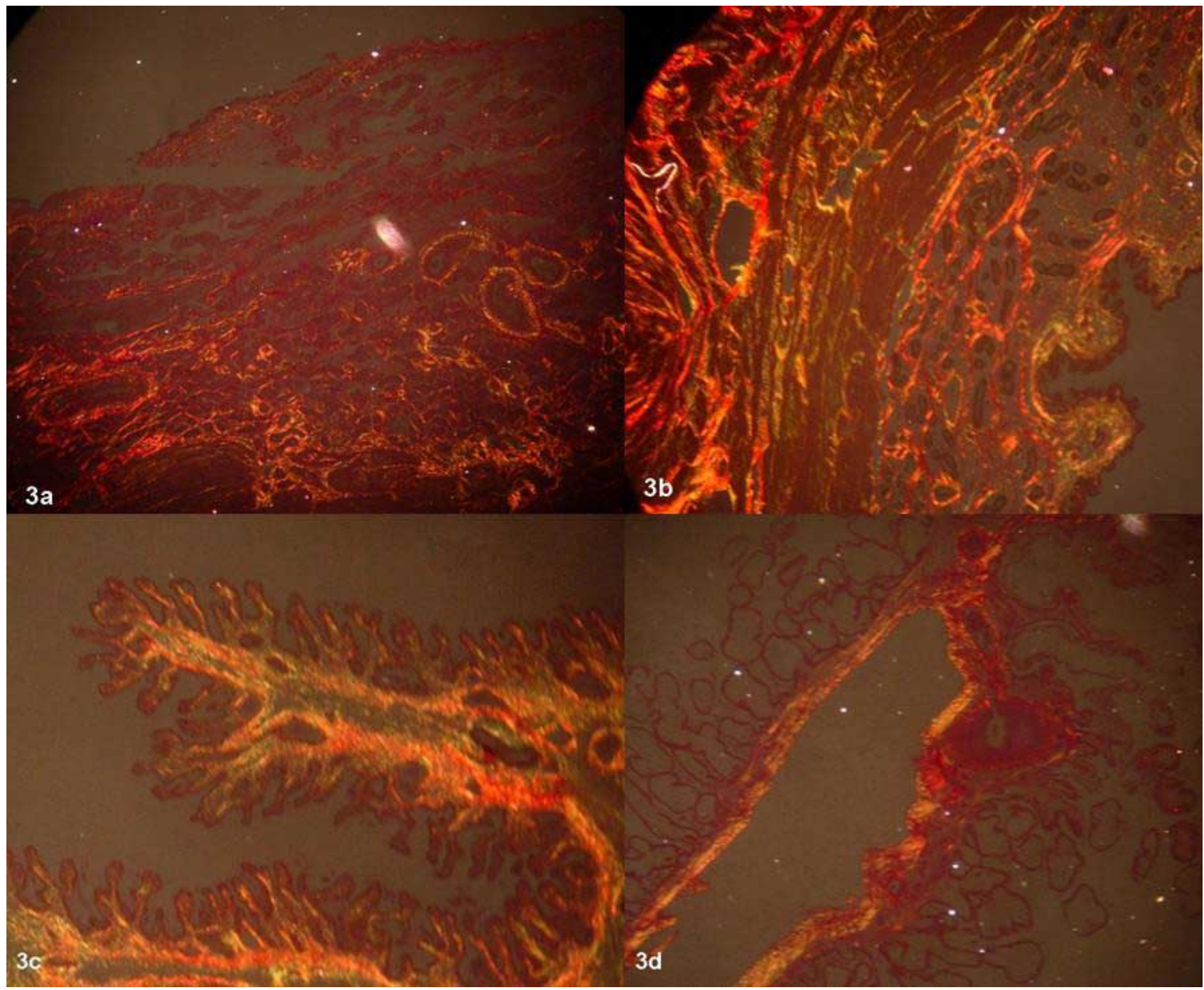

Fig. 3. Collagen staining by Picrosirius red at Day 30 (a, 100x), 60 (b, 400x), 70 (c, 200x) and 114 (d, 100x) of gestation in pigs.

\section{DISCUSSION}

This is the first work to study the presence of three extracellular matrix components in porcine placenta, and to analyze the possible interconnections among them. Results in crossbred gilts confirm the role of OPN as secretory product of endometrial glands binding to integrins present at uterine luminal epithelium and conceptus trophoectoderm to mediate an adequate placentation, as documented previously by our research group (Sanchis et al., 2009; Sanchis et al., 2010). This is in agreement with Garlow et 
al. findings at early gestation placental tissues. In more advanced pregnancy, the absence of this protein allows us to suggest the involvement of other molecules binding to integrins different from OPN (Sanchis et al., 2009). Precedents for uterine and placental expression of this molecule have already been reported in other species with placentation patterns differing from that present in pigs (Johnson et al.; Joyce et $a l$.). The decrease of OPN expression along gestation reinforces the idea that this protein is especially important in early periods of gestation not only as regulatory protein of implantation, but also ensuring adhesion and binding of the trophoectoderm to uterine luminal epithelium.

Immunoreactivity in conceptus trophoblast would indicate roles for OPN in mediating placental embryonic changes to favour uterus adhesion during placentation, as has been previously noted by Johnson et al. Moreover, our detection of OPN in histotroph and in fetal mesenchyme throughout pregnancy would be related to highly studied phenomena such as materno-fetal interaction, placentation, cell remodeling and cell-extracellular matrix interaction, all indispensable processes for pregnancy to succeed.

Immunoreactivity of $\mathrm{Fg}$ detected only at day 70 , in both maternal and fetal vessels, coincide with Merkis et al. who demonstrated that the density of blood vessels progresively increased between days 30 and 50 and presented the major augmentation due to great caliber vessels at day 70. It has been established that during the first half of gestation in mammals, there is an increase of placental angiogenesis to satisfy the metabolic demands of the concepti (Reynolds et al.). Furthermore, as component of the ECM, the fibrinogen participates in the regulation of hemostasis and generation of blood components necessary for an adequate vascularization (Iwaki et al.). Moreover, the high expression of this molecule found in endometrial connective and fetal mesenchyme tissues supports the fact that Fg is important to balance angiogenic processes and maintain tissue integrity to ensure a succesful pregnancy. This is in agreement with Iwaki et al. who found that deficiency in Fg in human placentas significantly alter placenta formation.

This is, to our undestanding, the first work in analyzing the presence of collagen fibers in porcine placental tissues and, even more, in an epitheliochorial placenta. Moreover, results reported here about collagen are similar to previously stated in other animal species (Arai \& Nishiyama), since collagen fibers augmented throughout gestation. This increase along porcine gestation is related to the structural remodeling and physiologic maturation of placenta to succesfuly accompany embryo development. We have already emphasized the relevance of collagen fibers (Merkis et al., 2009). Furthermore, the abundance of collagen fibers of different thickness in connective tissue and miometrium observed in the present work constitutes a clear evidence of the relevance of collagen system in the composition of porcine placental ECM, acting directly in the support of vascular and areola-gland systems. Our findings are similar to what has been reported by Arai and Nishiyama (Arai \& Nishiyama), who demonstrated that collagen concentrations in mouse placenta increased in the last third of gestation, suggesting the close involvement of these molecules in the production of ECM and proliferation of placental cells. Moreover, Sati et al. demostrated that collagen bundles have very specific arrangements in human placenta stem villi which would be related with functional activity.

Finally, to conclude, although the three molecules analyzed in the present study in pigs differ in structure and, consequentely, in function, their presence during pregnancy results essential to maintain placental integrity and allow a suitable nutrition of the embryo as well as an appropriate conceptus adhesion. It is necessary to deepen our knowledge about factors mediating and affecting pregnancy to develop some benefits applicable to pecuary activity in the future in order to diminish the high percentage of embryo loss in this high productive value species.

ACKNOWLEDGEMENTS. We would like to thank Nelcy Schleef in providing excellent technical assistance; Professors Silvia Beck and Iliana Martínez for language help; and Lic. Eber Cristofolini and Lic. Paula Armas in the use of polarizing microscopy.

SANCHIS, E. G.; CRISTOFOLINI, A. L.; TAGLIALEGNA, A. \& MERKIS, C. I. Moléculas de la matríz extracelular placentaria y uterina durante la preñez porcina. Int. J. Morphol., 29(4):1438-1443, 2011.

RESUMEN: Las moléculas que constituyen la matriz extracelular son importantes en varias funciones relacionadas con el soporte del tejido y la interacción célula-célula, célula-matriz extracelular. Entre las macromoléculas que constituyen la matriz mencionada se encuentra la osteopontina, el fibrinógeno y el colágeno. Este estudio se realizó para analizar el rol de la osteopontina, el fibrinógeno y el colágeno en la interface úteroplacentaria durante la gestación porcina normal. Tejidos uterinos y la placentarios de hembras porcinas cruzadas de $30(n=5), 60(n=$ 5), $70(\mathrm{n}=5)$ y 114 (a término, $\mathrm{n}=5$ ) días de gestación fueron utilizados. El análisis macroscópico de los embriones/fetos nos permitió determinar la edad gestacional por medio de la longitud cráneo-rabadilla. Tinciones de Hematoxilina-Eosina y Tricrómico de Masson con microscopía de luz se utilizó para estructurar el análisis de cada periodo de tiempo seleccionado de la gestación. Un estudio espacial y temporal de la osteopontina y el fibrinógeno se realizó mediante técnicas de inmunohistoquímica. La determinación de fibras colágenas se llevó a cabo a través de la técnica Picrosirius rojo por microscopia de polarización. Los resultados se expresaron como 
semi-cuantitativos. La expresión de osteopontina se observó en los primeros períodos de gestación, principalmente en las vellosidades del útero y la placenta, epitelio de las glándulas endometriales e histotrofos. El fibrinógeno se expresa abundantemente en mesénquima fetal en todos los períodos analizados y en los vasos fetales y maternos el día 70. Una expresión negativa de fibras colágenas se observó en las vellosidades, sin embargo, un aumento de expresión de las fibras gruesas durante la gestación se detectó en el estroma uterino y el miometrio. Estos resultados confirman la importancia de la osteopontina, fibrinógeno y colágeno en el soporte de las estructuras del útero y placenta, así como el mantenimiento adecuado durante la gestación.

PALABRAS CLAVE: Cerdo; Placenta; Osteopontina; Fibrinógeno; Colágeno.

\section{REFERENCES}

Arai, K. Y. \& Nishiyama, T. Developmental changes in extracellular matrix messenger RNAs in the mouse placenta during the second half of pregnancy: possible factors involved in the regulation of placental extracellular matrix expression. Biol. Reprod., 77(6):92333, 2007.

Cristofolini, A.; Merkis, C.; Barroso, F.; Vaquer, V.; Lloret, M.; Moschetti, E. \& Koncurat, M. Detección de fibrinógeno, FAS B10, FAS ZB4 y FAS C-20 durante la placentación porcina. REDVET, IX(7):1-10, 2008.

Esteban, F.; del Moral, M.; Sánchez-López, A.; Blanco, S.; Jiménez, A.; Hernández, R.; Pedrosa, J. \& Peinado, M. Colorimetric quantification and in situ detection of collagen. J. Biol. Educ., 39(4):1-4, 2005.

Garlow, J. E.; Ka, H.; Johnson, G. A.; Burghardt, R. C.; Jaeger, L. A. \& Bazer, F. W. Analysis of osteopontin at the maternal-placental interface in pigs. Biol. Reprod., 66(3):718-25, 2002.

Iwaki, T. \& Castellino, F. J. Maternal fibrinogen is necessary for embryonic development. Curr. Drug Targets, 6(5):535-9, 2005.

Iwaki, T.; Sandoval-Cooper, M. J.; Paiva, M.; Kobayashi, T.; Ploplis, V. A. \& Castellino, F. J. Fibrinogen stabilizes placental-maternal attachment during embryonic development in the mouse. Am. $J$. Pathol., 160(3):1021-34, 2002.

Johnson, G. A.; Burghardt, R. C.; Bazer, F. W. \& Spencer, T. E. Osteopontin: roles in implantation and placentation. Biol. Reprod., 69(5):1458-71, 2003.

Joyce, M. M.; González, J. F.; Lewis, S.; Woldesenbet, S.; Burghardt, R. C.; Newton, G. R. \& Johnson, G. A. Caprine uterine and placental osteopontin expression is distinct among epitheliochorial implanting species. Placenta, 26(2-3):160-70, 2005.

Kuehl, R. Diseño de experimentos. Principios estadísticos de diseño y análisis de investigación. $2^{\mathrm{a}}$ ed. México, Thomson, 2001.
Marrable, A. W. The embryonic pig: a chronological account. London, Pitman Medical, 1971.

Merkis, C. I.; Cristofolini, A. L.; Franchino, M. A.; Moschetti, E. \& Koncurat, M. A. Relación entre área total y área epitelial de vellosidades placentarias porcinas en diferentes estadíos gestacionales. InVet, 7(1):47-54, 2005.

Merkis, C.; Cristofolini, A.; Franchino, M.; Sanchis, E.; Moschetti, E. \& Koncurat, M. Angiogénesis placentaria durante la gestación porcina. REDVET, 7(4):1-4, 2006.

Merkis, C.; Cristofolini, A.; Sanchis, G.; Chanique, A.; Moschetti, E.; Campos, M.; Taglialegna, A.; Alessio, A.; Allende, F. \& Koncurat, M. Localization of collagen through Picrosirius red in porcine placenta. Biocell, 33 (3):A256, 2009.

Ramos-Vara, J. A. Technical aspects of immunohistochemistry. Vet. Pathol., 42(4):405-26, 2005.

Rashev, P.; Georgieva, R. \& Rees, D. Expression of alpha5beta1 integrin and fibronectin during early pregnancy in pigs. Folia Biol. (Praha), 51(5):121-5, 2005.

Reynolds, L. P.; Caton, J. S.; Redmer, D. A.; Grazul-Bilska, A. T.; Vonnahme, K. A.; Borowicz, P. P.; Luther, J. S.; Wallace, J. M.; Wu, G. \& Spencer, T. E. Evidence for altered placental blood flow and vascularity in compromised pregnancies. J. Physiol., 572(Pt 1):51-8, 2006.

Rich, L. \& Whittaker, P. Collagen and Picrosirius red staining: A polarized light assessment of fibrillar hue and spatial distribution. Braz. J. Morphol. Sci., 22(2):97-104, 2005.

Sanchis, E. G.; Cristofolini, A. L.; Merkis, C. I.; Chanique, A. M. L.; Moschetti, E. \& Koncurat, M.A. Preliminary results of osteopontin immunoexpression in porcine placenta. Anat. Histol. Embryol., 39:87, 2010.

Sanchis, G.; Williamson, D.; Cristofolini, A.; Merkis, C. \& Koncurat, M. Osteopontin and avb3 integrin inmunoexpression in porcine placental tissues. Preliminary study. Biocell, 33(3):A256, 2009.

Sati, L.; Demir, A. Y.; Sarikcioglu, L. \& Demir, R. Arrangement of collagen fibers in human placental stem villi. Acta Histochem., 110(5):371-9, 2008.

Wooding, P. \& Burton, G. Comparative placentation. Structures, functions and evolution. Berlin, Springer-Verlag, 2008.

Correspondence to:

Eva Gabriela Sanchis

Facultad de Agronomía y Veterinaria

Universidad Nacional de Río Cuarto

Ruta Nac. 36, km 601. Código Postal X5804BYA

Río Cuarto, Córdoba

ARGENTINA

Received: 24-06-2011

Email:gsanchis@ayv.unrc.edu.ar microbiologa.gsanchis@gmail.com
Accepted: 08-09-2011 